\title{
Fracture resistance of various laminate veneer materials: systematic literature review
}

\section{Odporność na złamania materiałów wykorzystywanych w wykonawstwie licówek - systematyczny przegląd piśmiennictwa}

\author{
Rugilė Bondzinskaitė ${ }^{1}$, Greta Venskutė ${ }^{1}$, Albertas Kriaučiūnas ${ }^{2}$ \\ ${ }^{1}$ Faculty of Odontology, Medical Academy, Lithuanian University of Health Sciences, Lithuania \\ Wydział Odontologii Akademii Medycznej Litewskiego Uniwersytetu Nauk o Zdrowiu, Litwa \\ Haed: Prof. Dainius Razukevičius \\ ${ }^{2}$ Department of Prosthodontics, Lithuanian University of Health Sciences, Lithuania \\ Katedra Protetyki, Litewski Uniwersytet Nauk o Zdrowiu, Litwa \\ Haed: Prof. Gediminas Žekonis
}

KEY WORDS:

laminate veneer, fracture, resistance, ceramics

\section{Summary}

Aim of the study. To investigate the resistance of the most commonly used laminate veneer materials (lithium disilicate, feldspatic ceramic, zirconia-reinforced lithium silicate) to fracture.

Materials and methods. This article follows the Preferred Reporting Items for Systematic Reviews and Meta-Analysis (PRISMA) statement. The literature search was performed in PubMed, Wiley Online Library and ScienceDirect databases, for articles published between 2016 and 2021 in the English language. The included studies were evaluated for the risk of bias following a preestablished criterion.

Results. 481 publications were found, out of which 13 were identified as relevant to the topic. There was a noticeable relation between the choice of restoration materials and fracture strength. Most of the included studies (69.2\%) evaluated the lithium disilicate material for fracture resistance. The posterior teeth group was used more often for fracture resistance tests in comparison to anterior teeth group. Thermomechanical aging was performed in 8 out of 13 studies $(61.5 \%)$.
HASŁA INDEKSOWE:

licówki, złamania, odporność, ceramika

\section{Streszczenie}

Cel pracy. Celem pracy byt przeglad piśmiennictwa dotyczącego odporności na złamania najczęściej wykorzystywanych materiatów do wykonawstwa licówek dentystycznych (dwukrzemian litu, ceramiki feldszpatowej, krzemianu litu wzmacnianego tlenkiem cyrkonu).

Material i metody. Artykut sporzadzono zgodnie z Preferencjami Raportowania dla Przegladów Systematycznych i Meta-Analiz (Preferred Reporting Items for Systematic Reviews and Meta-Analysis) - PRISMA. Bazy PubMed, Viley Online Library oraz ScienceDirect zostaty przeszukane $w$ zakresie lat 2016-2021 z preferencja poszukiwania artykutów $w$ języku angielskim. Badania wtaczone do pracy zostaty ocenione pod kątem ryzyka stronniczości zgodnie z wcześniej ustalonym kryterium.

Wyniki. Odnaleziono 481 publikacji, z czego 13 zostało zakwalifikowanych jako istotne dla zatożonego celu pracy. Zauważono zwiazek pomiędzy doborem materiatów odbudowy a wytrzymałościa na złamania. Większość zakwalifikowanych badań $(69,2 \%)$ oceniato ceramike dwukrzemowo-litowa pod katem odporności na zlamania. 
Conclusions. Zirconia-reinforced lithium silicate and resin nanoceramic veneers showed more favourable outcomes in their resistance to fracture. Therefore, the preparation of substantial tooth structure causes higher probability of fracture occurrence.

\section{Introduction}

Over the past years, aesthetic dentistry has gradually developed into a significant aspect of restorative dentistry, particularly in the area of veneer placement, owing to the resulting favourable aesthetic and long-term outcomes. ${ }^{1}$ Laminate veneers constitute a minimally invasive and highly aesthetic treatment that was introduced in 1928 by a California dentist Charles Pincus. ${ }^{2}$ Dr. Charles Pincus was the first to develop veneers using acrylic material. Due to its inadequate resilience affectingits clinical performance, laminate veneers have since been continuously improved. As it is noted, a variety of different materials with a huge range of constituents can be used for their manufacturing, yet in most cases porcelain and composite usage is customary.

Porcelain veneers offer excellent aesthetic results and predictable longevity of treatment, while composite veneers can be considered as a good conservative option, but with less durability. ${ }^{3}$ Regardless of that, based on unequivocal properties, comparably low costs and ease of fabrication, ${ }^{4}$ a number of ceramic materials are currently preferable for veneers: feldspathic ceramic, lithium disilicate, leucite-reinforced feldspathic ceramic, fluorapatite and lithium silicate reinforced with zirconia. ${ }^{5}$
W publikacjach częściej wykorzystywano odbudowy zębów bocznych, aniżeli grupy zębów przednich $w$ testach wytrzymatości na złamania. Termomechaniczne starzenie próbek byto dokonane $w 8$ z 13 badań $(61,5 \%)$.

Wnioski. Ceramiki litowo-krzemowe wzmacniane cyrkonem i nanoceramiki wykorzystywane do wykonawstwa licówek wykazuja korzystniejsze wyniki w testach wytrzymałości na złamanie. Wobec tego preparacja znacznej ilości tkanek zęba powoduje zwiększenie możliwości powstania złamania.

Referred materials possess diverse acclaimed properties that establish their significantly better performance compared to others. Firstly, they offer more prominent optical features that are obtained due to their excessive content of glassy matrix in their composition, which causes high translucency rate, ${ }^{6}$ therefore a highly favourable aesthetics outcome is achieved. Additionally, they not only demonstrate excellent adhesion to resin cement through the conditioning with hydrofluoric acid (4-10\%) followed by silanization, ${ }^{7}$ but also contain quite high mechanical strengths. Introduced assets are among the many that predetermine their favourability at the present time. Correspondingly, determining properties such as resistance to fracture and durability also have a prominent influence on their use. Both of these properties are particularly contingent on one another, and are of upmost importance when it comes to ceramic veneers, reliability and acceptable clinical performance.

Fracture resistance needs to be contemplated while selecting a restorative material, and it is of particular significance as the main factor when choosing a particular one to obtain proper stress distribution during mastication process. Consequently, the selection of materials plays a crucial role in the lifespan of restorations, as each material has its own composition 
and properties. ${ }^{8}$ Furthermore, the chosen type of material can reduce labour cost and shorten the manufacturing processes, provided that it properly integrates with automated equipment in the laboratory used for veneer production. Additionally, it is noted that fundamentally during veneer construction, beneath decrepit porcelain veneer, a solid and inflexible substructure is placed that should resist flexure and, as a consequence, during the occurrence of tensile strength this layered structure will avert fracture. This way, the chosen material ought to be evaluated taking into consideration this particular property. ${ }^{9}$ And yet, studies of the effects of material and substructure design on fracture resistance are sparse even though the microstructure is directly related to long-term ceramic behaviour. ${ }^{10,11}$

The aim of this systematic review was to evaluate scientific literature on ceramic materials that are used for laminate veneers manufacturing, with regard to their fracture resistance.

\section{Materials and methods}

\section{Information source and the search strategy}

A systematic literature search was performed according to the PRISMA guidelines for clinical trials and literature analysis published between 2016 and 2021. Electronic literature searches were picked from 2021 May to July independently by all authors in English databases: PubMed, Wiley Online Library and ScienceDirect. Databases were searched using different combinations of the following key words: laminate veneer resistance, laminate veneer fracture. ("laminate veneers" OR "laminate" OR "veneers" OR "ceramic" AND "fracture" OR "resistance" NOT "implant" NOT "crowns"). The titles and abstracts were analysed by the three authors, followed by the selection of complete articles for careful reviewing and analysis according to the eligibility criteria.

\section{Study selection}

The selected articles passed four stages:

- Selection by the relevant article title,

- Duplicate removal,

- Selection by the relevance of the abstract,

- Full text analysis.

\section{Article inclusion criteria:}

The selected papers in this systematic review were laboratory studies, case reports, and clinical studies written in English and were not older than five years. Included studies evaluated the fracture resistance of laminate veneers. The research question was: which laminate veneering material is the most resistant to fracture?

\section{Article exclusion criteria:}

During the evaluation process subsequent studies were eliminated: studies that were published before 2016 and after 2021, written in a language other than English. Moreover, clinical studies that used endodontically treated teeth, or traumatized teeth were excluded. Therefore, all laboratory studies that evaluated implant-supported restorations were also excluded. All laboratory studies that assessed full-coverage crowns, 4-unit prostheses, inlays or onlays were also excluded. Pilot studies and studies that used testing methodologies other than fracture or fatigue strength were also excluded.

\section{Results}

\section{Search outcomes}

Overall, the initial search strategies generated 481 articles. After the first evaluation duplicates were identified and excluded. After screening, 288 potential articles were selected for full article review and 156 were excluded. This systematic review included 13 studies that were conducted to evaluate laminate veneer materials fracture resistance. The article search and selection process is presented in the PRISMA flow chart (Figure 1). 


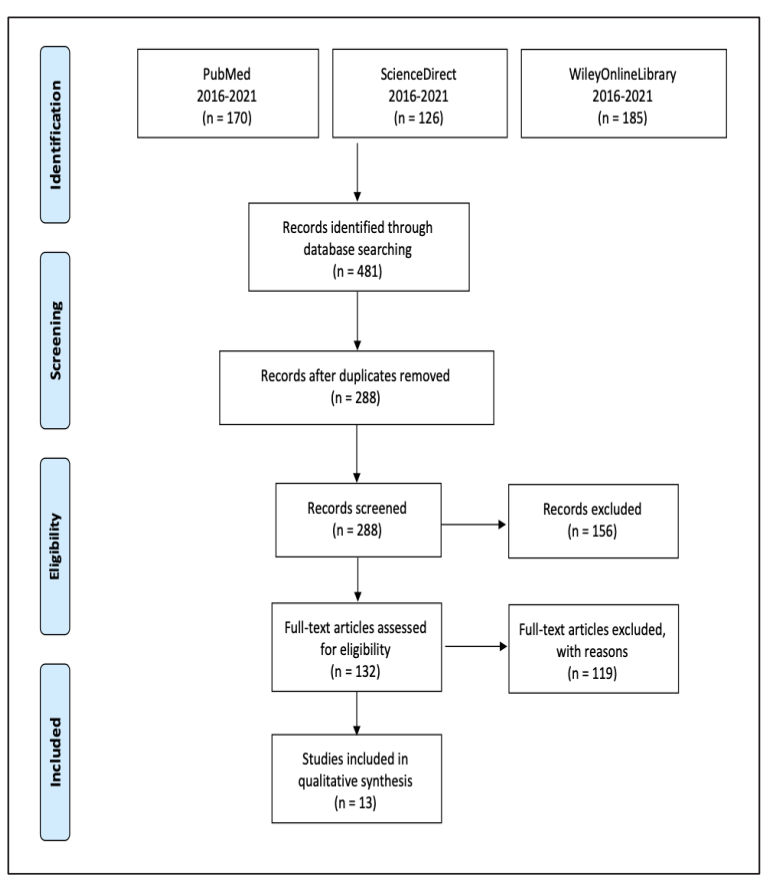

Fig. 1. PRISMA flow chart.

\section{Study characteristics}

The PICO of this systematic review was defined in Table 1, which lists different aging methodologies, failure mode and survival probability among studies.

In 8 studies ${ }^{7,8,10,12,13,15,18,19}$ thermomechanical aging was performed, where the number of cycles varied from 2000 to $3,000,000$, therefore the 1,200,000 cycles were performed in four ${ }^{12,15,18,19}$ of the eight studies. In three studies, ${ }^{6,11,14}$ specimens were subjected to fracture resistance tests after cyclic loading. The stepstress accelerated life-testing (SSALT) test was applied in two studies. ${ }^{16,17}$

In the first study ${ }^{6}$ after 20,000 cycles with compressive load of $100 \mathrm{~N}$, the fracture without tooth structure involvement in the occlusal surface coverage and the occlusal and lingual surface coverage types of veneers occurred in $62.5 \%$ of cases, whereas in the occlusal, lingual, and mesial surface coverage and the occlusal, lingual, mesial, and distal surface coverage types of veneers the percentage was 75 .
In the second study, ${ }^{7}$ fracture resistance of translucent zirconia laminates has been affected by the sintering procedure - when standard sintering was applied in the incisal palatal chamfer preparation design group, cohesive failure was $20 \%$ compared to speed sintering where the cohesive failure increased to $50 \%$.

In the third study, ${ }^{8}$ after a two-year simulated period, the fracture frequency in Vita Enamic hybrid ceramic group was $44.4 \%$, whereas in the IPS e.max CAD - lithium disilicate glassceramic group - the figure was $66.7 \%$.

In the fourth study, ${ }^{10} 90$ incisors were used. After 10.000 cycles (which simulated a year) with a force of $300 \mathrm{~N}$, metal ceramic and zirconia-lithium disilicate exhibited more favourable fracture resistance than zirconia-feldspathic porcelain. The substructure design with increased coverage of the palatal surface improved fracture resistance significantly.

In the fifth study, ${ }^{11}$ zirconia-reinforced lithium silicate (ZLS) and hybrid ceramic (polymer-infiltrated ceramic - PIC) in two thicknesses $(0.5 \mathrm{~mm}$ and $1 \mathrm{~mm})$ were used. All specimens received an initial load of $200 \mathrm{~N}$ for 5,000 cycles, testing was limited to a maximum of $1.5 \times 10^{6}$ cycles. After $5 \times 10^{5}$ cycles at $450 \mathrm{~N}$ ZLS.5 presented lower fatigue strength (25\%) compared with PIC.5 and PIC1 (83\%).

In the sixth study, ${ }^{12}$ after thermomechanical fatigue (1.2 million cycles at $98 \mathrm{~N}$ with $5^{\circ} \mathrm{C}-55^{\circ} \mathrm{C}$ ) the zirconia-reinforced lithium silicate group showed the highest $62.5 \%$ survival rate while the polymethylmethacrylate group demonstrated the lowest $37.5 \%$ one.

After 3,000,000 cycles with up to $100 \mathrm{~N}$, the seventh study ${ }^{13}$ showed that the fracture risk increased with thin anterior veneers and also when the preparation included medium to high dentine portions (invasive preparation design) compared to thicker ones with preparations in the enamel or partially in the dentine (semiinvasive).

In the eighth study, ${ }^{14}$ IPS e.max CAD showed 


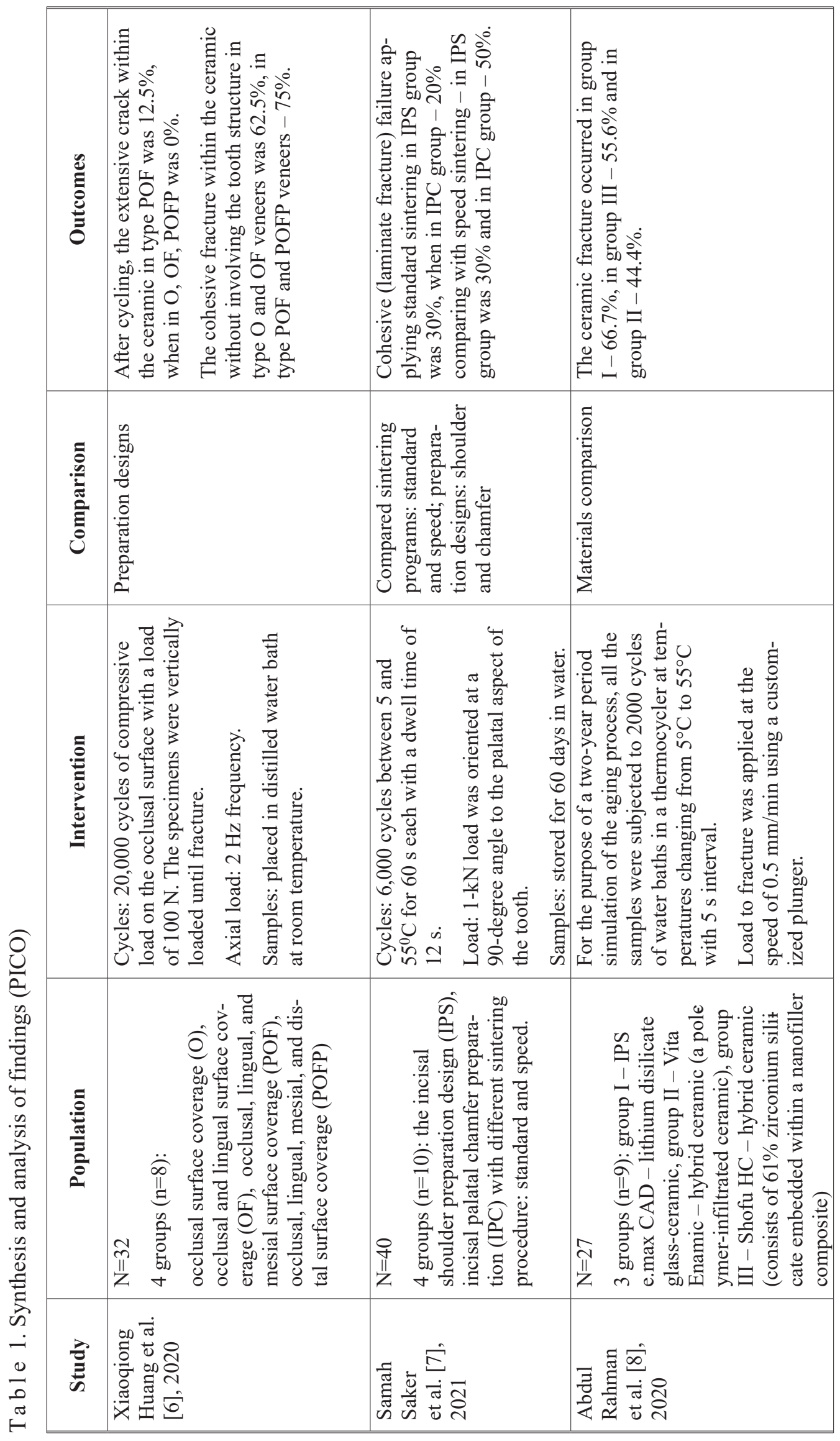




\begin{tabular}{|c|c|c|c|}
\hline 苞 & 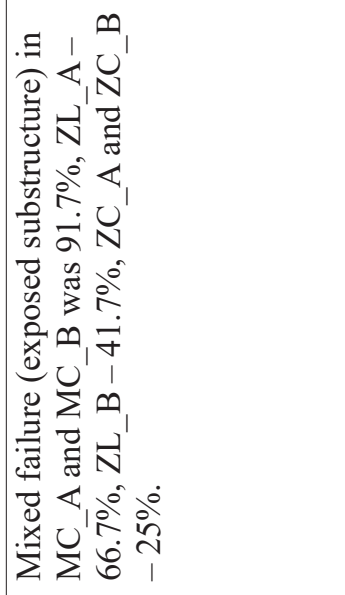 & 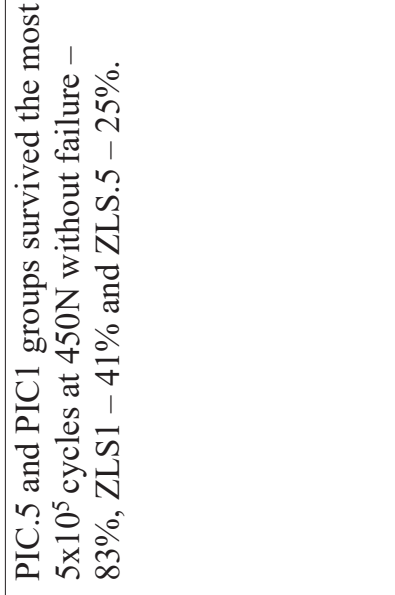 & 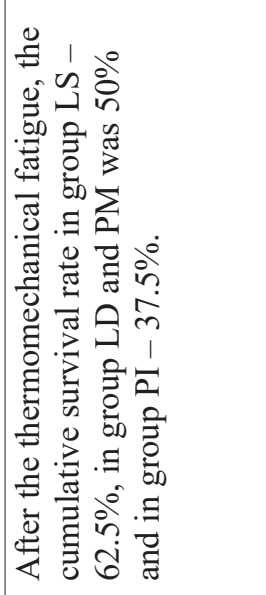 \\
\hline 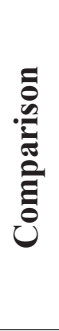 & 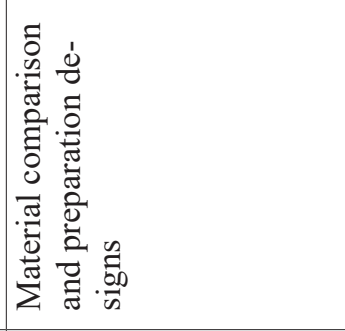 & 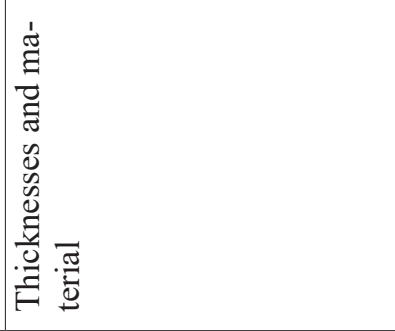 & 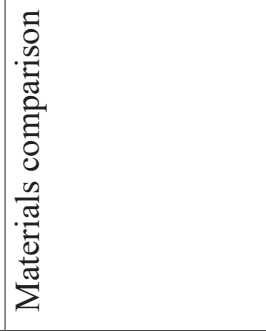 \\
\hline 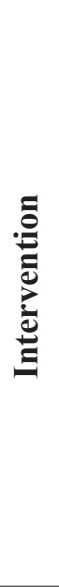 & 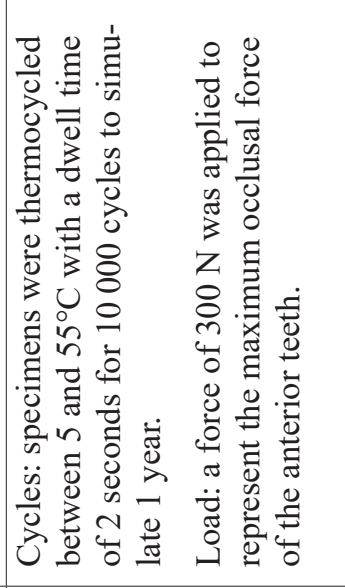 & 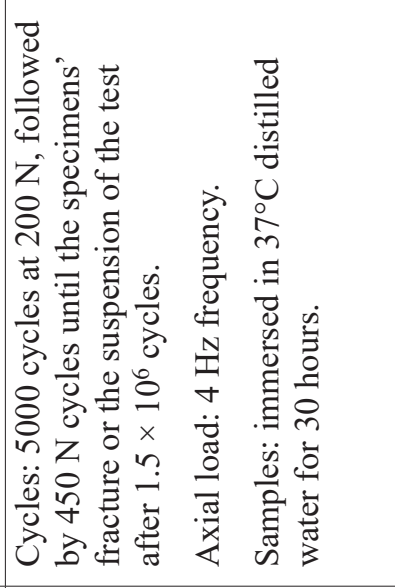 & 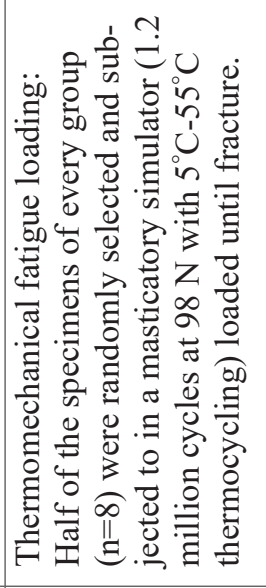 \\
\hline & 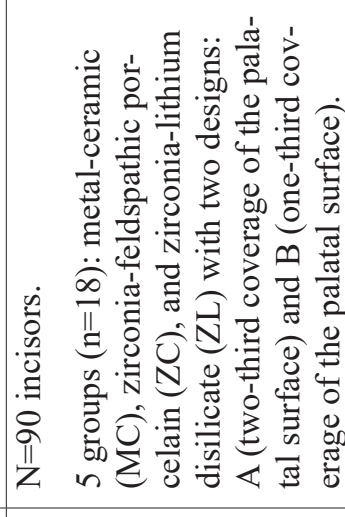 & 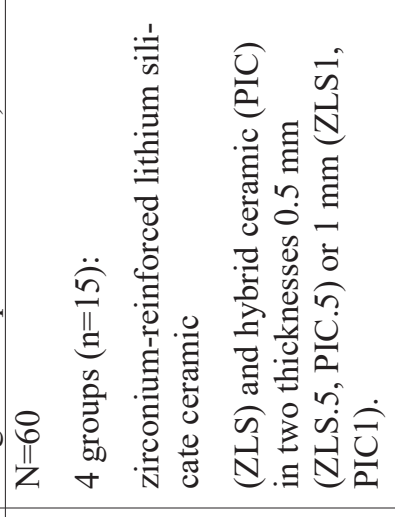 & 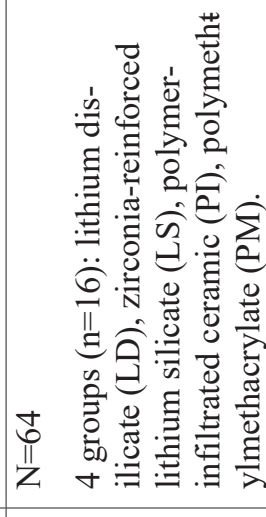 \\
\hline$\stackrel{\vec{E}}{\stackrel{\vec{E}}{\infty}}$ & 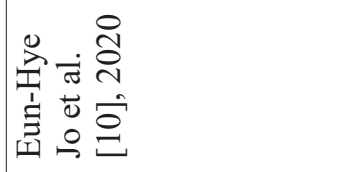 & 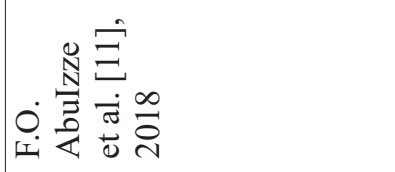 & 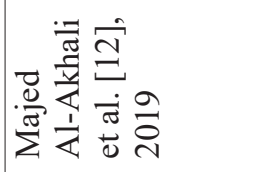 \\
\hline
\end{tabular}




\begin{tabular}{|c|c|c|c|}
\hline $\begin{array}{l}\stackrel{0}{E} \\
\stackrel{0}{0} \\
0\end{array}$ & 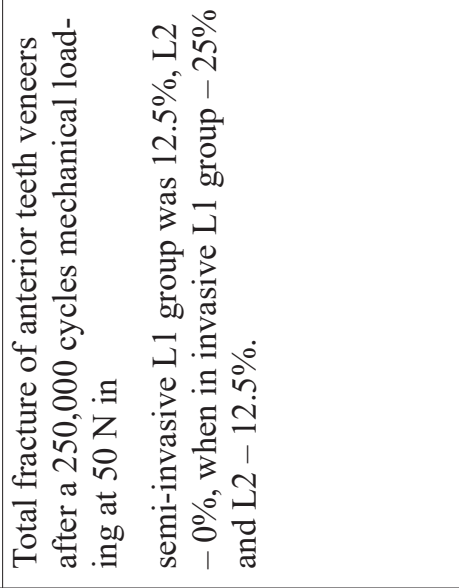 & 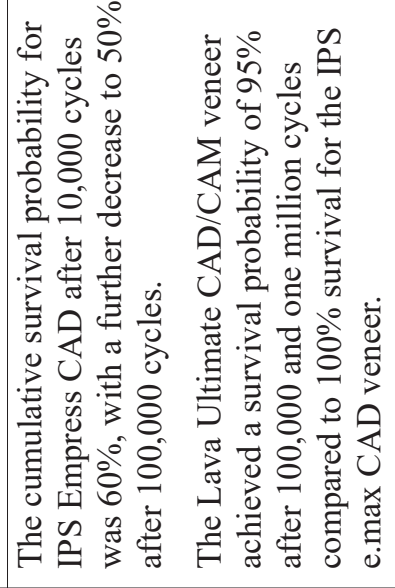 & 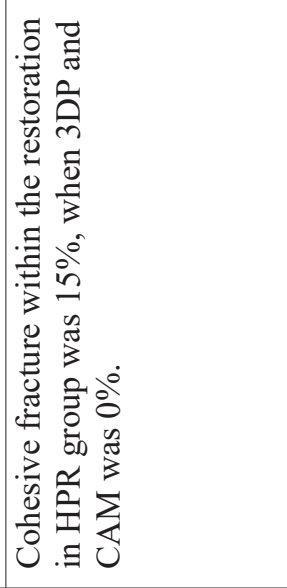 \\
\hline 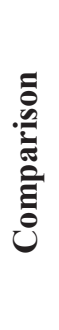 & 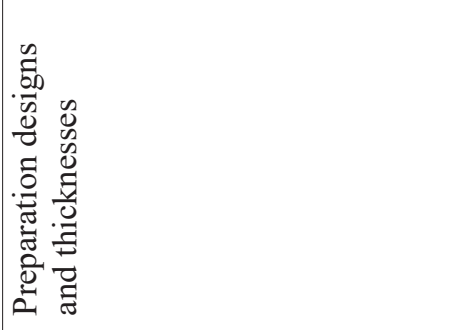 & 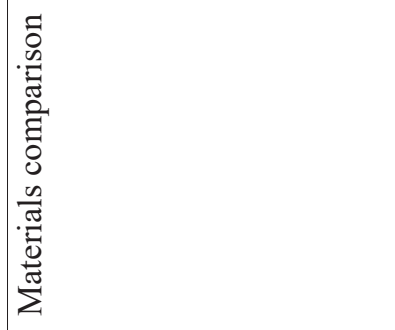 & 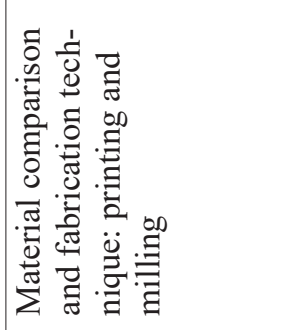 \\
\hline 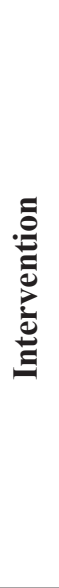 & 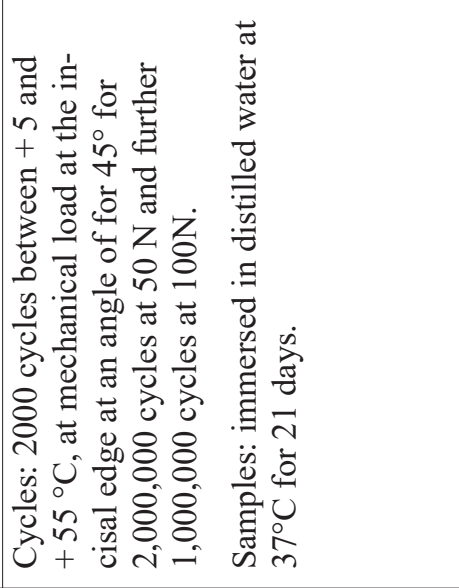 & 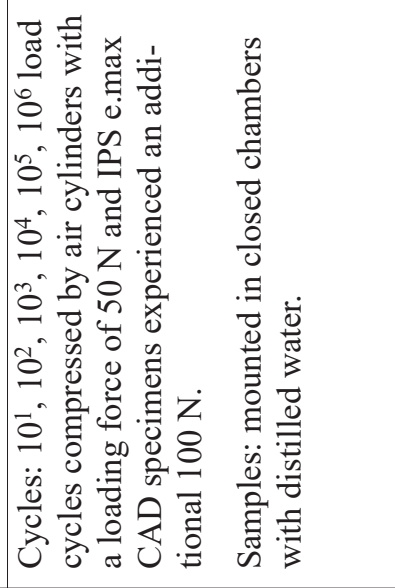 & 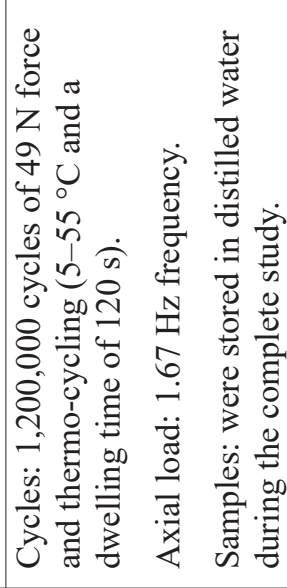 \\
\hline & 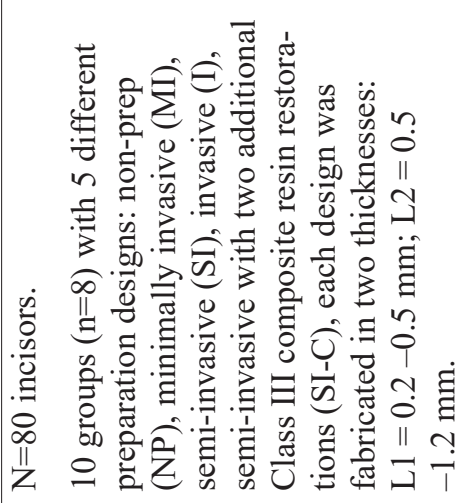 & 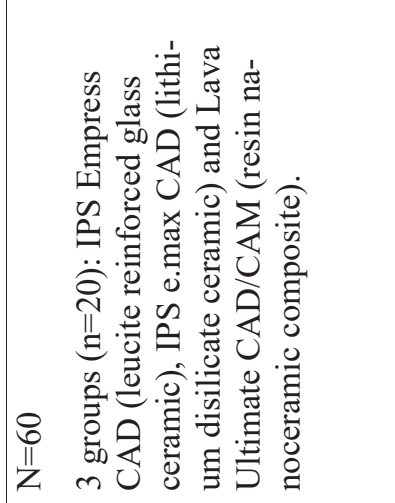 & 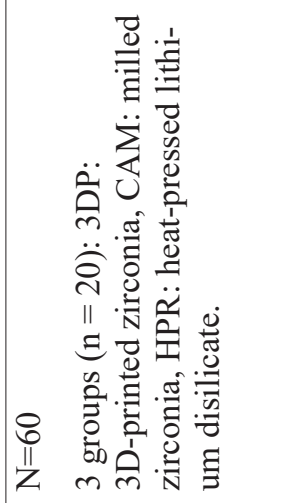 \\
\hline $\begin{array}{l}\vec{E} \\
\stackrel{E}{E}\end{array}$ & 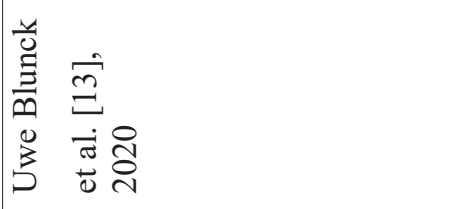 & 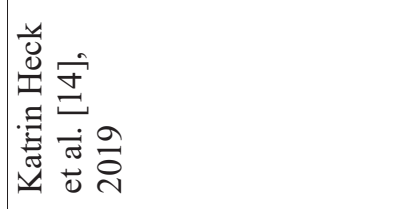 & 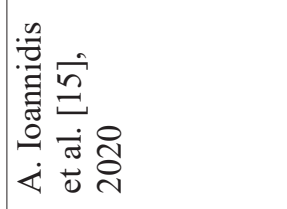 \\
\hline
\end{tabular}




\begin{tabular}{|c|c|c|c|c|}
\hline 嶽 & 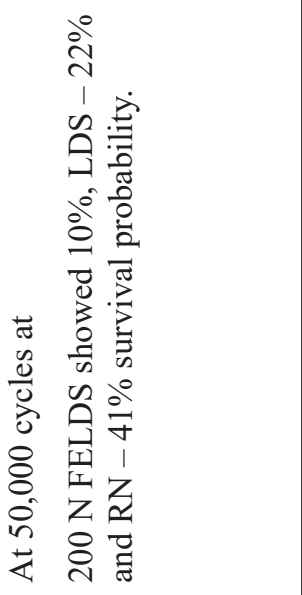 & 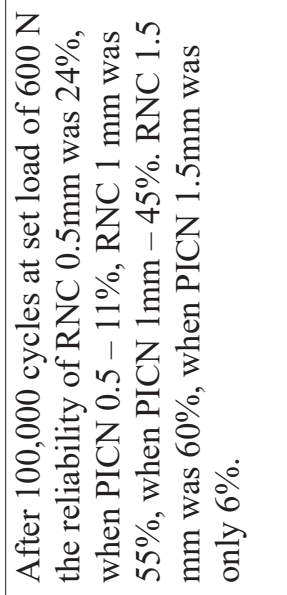 & 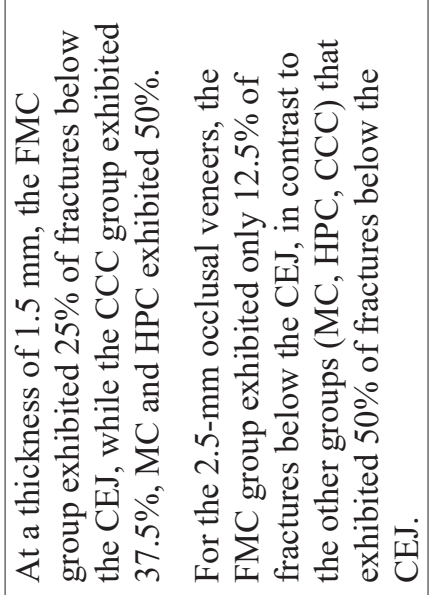 & 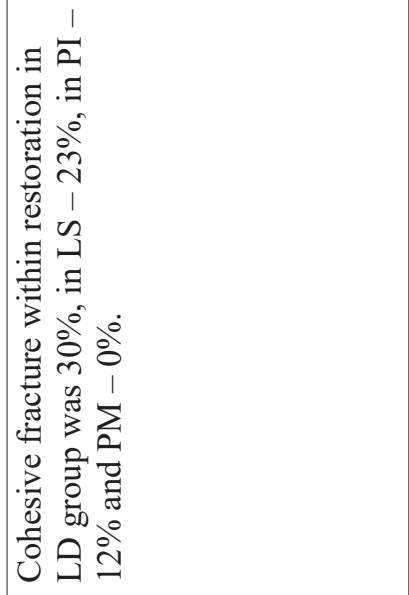 \\
\hline 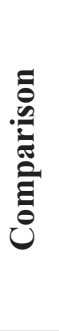 & 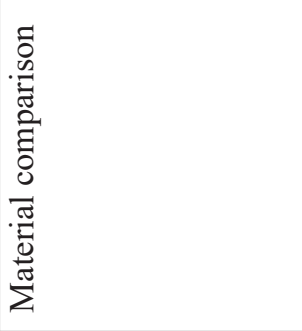 & 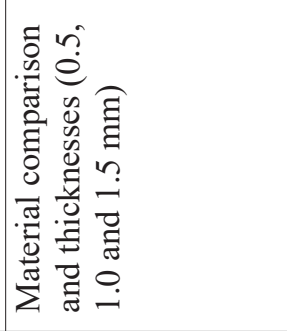 & 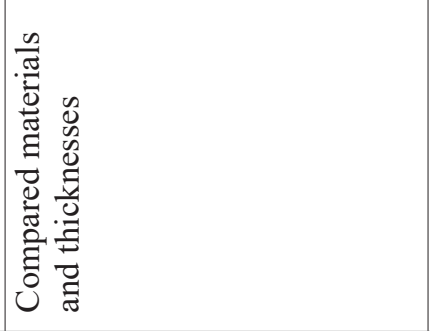 & 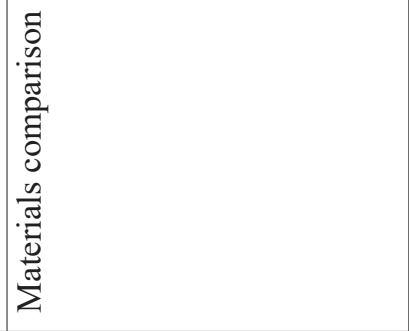 \\
\hline 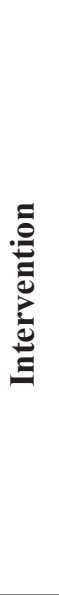 & 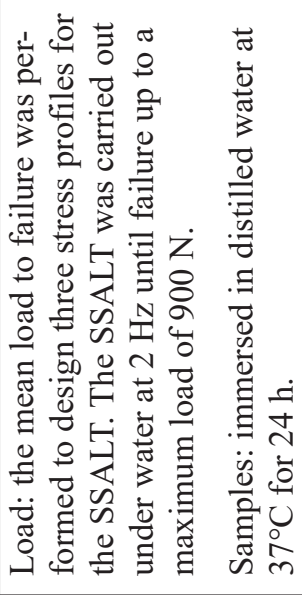 & 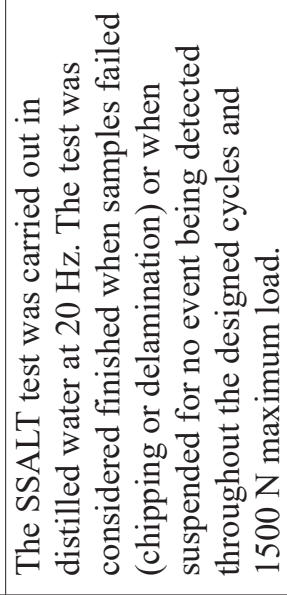 & 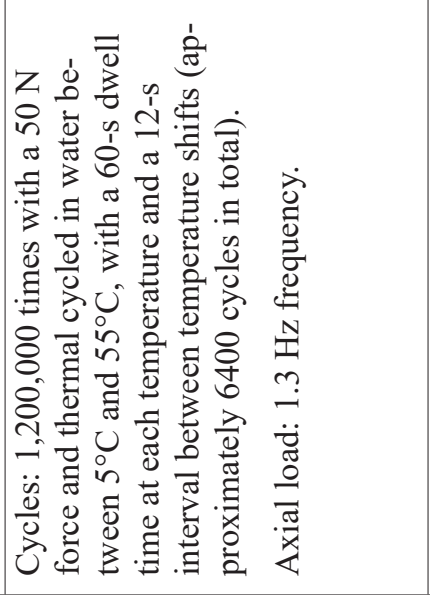 & 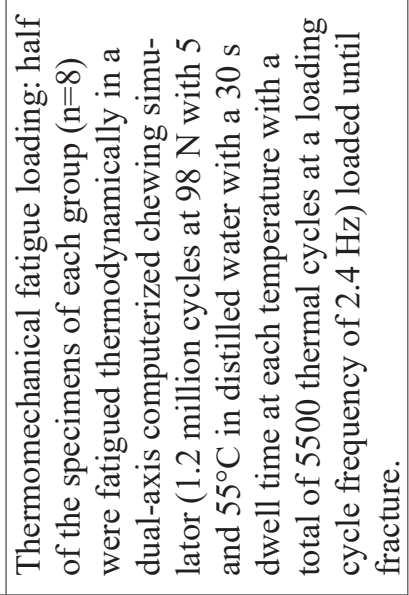 \\
\hline & 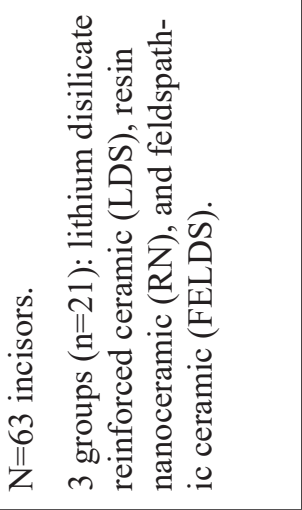 & 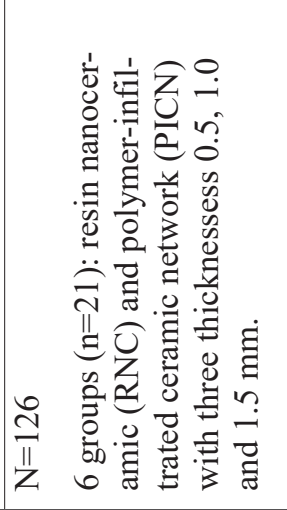 & 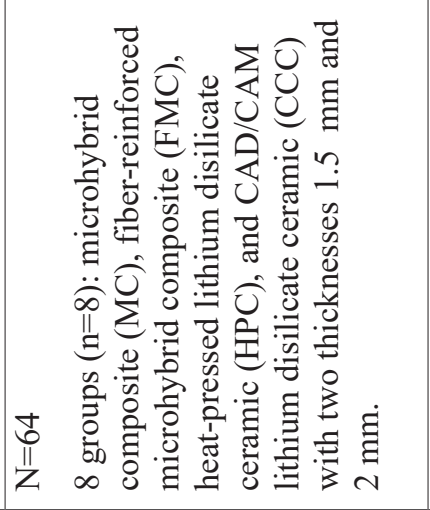 & 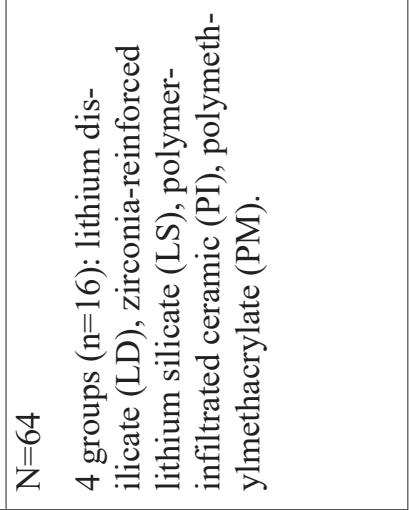 \\
\hline$\stackrel{\vec{E}}{\stackrel{Z}{E}}$ & 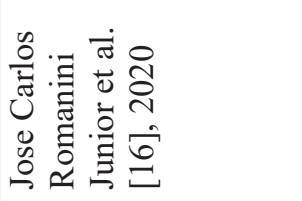 & 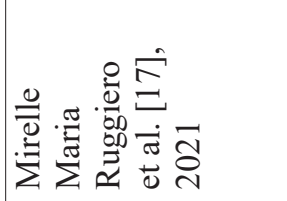 & 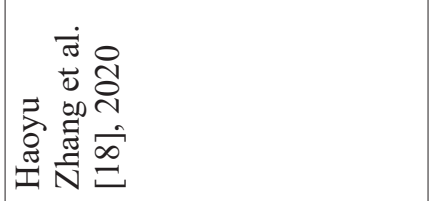 & 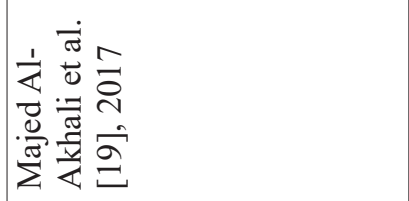 \\
\hline
\end{tabular}


significant survival rate $(100 \%)$ after $1,000,000$ load cycles with a $150 \mathrm{~N}$ loading force, when only $60 \%$ of IPS Empress CAD veneers survived after 10,000 cycles with a $50 \mathrm{~N}$ loading force.

In the ninth study, ${ }^{15}$ after $1,200,000$ cycles of $49 \mathrm{~N}$ load and thermocycling, $15 \%$ of the heatpressed lithium disilicate specimens were subject to cohesive fracture within the restoration, while none of the 3D-printed and milled zirconia specimens experienced fracture.

In the tenth study, ${ }^{16} 63$ incisors were used. After 50,000 cycles at $200 \mathrm{~N}$, the probability of survival was significantly lower for the feldspathic ceramic (10\%), whereas lithium disilicate-reinforced ceramic presented intermediate values $(22 \%)$ compared to resin nanoceramic veneers $(41 \%)$.

In the eleventh study, ${ }^{17}$ after 100,000 cycles at the set load of $600 \mathrm{~N}$ the survival rate was higher for resin nanoceramic than polymerinfiltrated ceramic. Therefore, the restoration thicknesses increased the survival rate: when the nanoceramic thickness was $0.5 \mathrm{~mm}$, reliability was only $24 \%$. When the thickness was $1.5 \mathrm{~mm}$, reliability rose to $60 \%$.

In the twelfth study, ${ }^{18}$ after $1,200,000$ cycles with a force of $50 \mathrm{~N}$ and thermocycling, resistance of different materials and thicknesses to fracture varied. Microhybrid composite with the thickness of $1.5 \mathrm{~mm}$ and heat-pressed lithh ium disilicate ceramic groups exhibited $50 \%$ of fractures below the cemento-enamel-junction (CEJ), unlike the fiber-reinforced min crohybrid composite group, which exhibited $25 \%$. For the $2.5 \mathrm{~mm}$ occlusal veneers, the fibre-reinforced microhybrid composite group exhibited merely $12.5 \%$ of fractures below the CEJ, while the microhybrid composite, heat-pressed lithium disilicate ceramic and CAD/CAM lithium disilicate ceramic exhibited $50 \%$ of fractures.

In the thirteenth study, ${ }^{19}$ after the thermomechanical fatigue loading, in the lithium disilicate group the cohesive fracture within the restoration accounted for $30 \%$, followed by zirconia-reinforced lithium silicate $-23 \%$ and polymer-infiltrated ceramic $-12 \%$, while in the polymethylmethacrylate group no fractures were observed.

\section{Risk of bias - assessment of quality}

Risk of bias was assessed with Cochrane Risk of Bias version 2 tool. Results are presented in Figure 2. Overall, no studies have shown high risk of bias; eight studies showed some concerns while five studies indicated low risk of bias.

\begin{tabular}{|c|c|c|c|c|c|c|c|c|c|c|c|}
\hline Experimental & Comparator & Outcome & Weight & D1 & $\underline{\mathrm{D} 2}$ & $\underline{\mathrm{D}}$ & $\underline{\mathrm{D}}$ & $\underline{05}$ & Overall & & \\
\hline Majed Al-Akhali et a 1 & NA & NA & 1 & 1 & + & + & + & + & + & + & Low risk \\
\hline F. 0. Abulzze et al.,; 1 & NA & NA & 1 & C & + & + & + & + & (1) & 1 & Some concerms \\
\hline Uwe Blunck et al., 201 & NA & $\mathrm{NA}$ & 1 & 1 & + & + & + & 1 & (1) & C & High risk \\
\hline Kattin Heck et al., 201 & NA & NA & 1 & 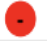 & + & + & + & + & (1) & & \\
\hline Xiaogiong Huang et $\tilde{\varepsilon} 1$ & NA & NA & 1 & $!$ & + & + & + & 1 & (1) & D1 & Randomisation process \\
\hline A. Ionnidis et al., 2021 & NA & NA & 1 & $!$ & + & + & + & + & + & D2 & Deviations from the intended interventions \\
\hline Eun-Hye Jo et al., 20: 1 & $\mathrm{NA}$ & NA & 1 & $\theta$ & + & + & + & + & (1) & D3 & Missing outcome data \\
\hline Jose Carlos Romanini 1 & NA & NA & 1 & $\odot$ & + & + & + & + & (1) & D4 & Measurement of the outcome \\
\hline Mirelle Maria Ryggie 1 & NA & NA & 1 & $\theta$ & + & + & + & + & (1) & D5 & Selection of the reported result \\
\hline Samah Saker et al., i 1 & NA & NA & 1 & 1 & + & + & + & 1 & (1) & & \\
\hline Haoyu Zhang et al., i 1 & NA & NA & 1 & 1 & + & + & + & + & + & & \\
\hline Abdul Rahman Moh: 1 & NA & NA & 1 & 1 & + & + & + & + & + & & \\
\hline Majed Al-Akhali et a 1 & NA & NA & 1 & 1 & + & + & + & + & $\oplus$ & & \\
\hline
\end{tabular}

Fig. 2. Quality assessment using Cochrane Risk of bias version 2 tool. 


\section{Assessment of mechanical test parameters}

$\mathrm{Six}^{6-8,10,14,16}$ out of thirteen studies used $0.5 \mathrm{~mm} / \mathrm{min}$ crosshead speed. Three ${ }^{15,17,18}$ studies used a crosshead speed of $1.0 \mathrm{~mm} / \mathrm{min}$. Two studies used crosshead speed of $1,800 \mathrm{~mm} /$ $\min ^{12,19}$ and one ${ }^{13}$ study $-1,020 \mathrm{~mm} / \mathrm{min}$. In five studies a stainless-steel sphere with diameters of $4.6 \mathrm{~mm},{ }^{6,11} 4 \mathrm{~mm},{ }^{6} 6 \mathrm{~mm},{ }^{10} 5.5 \mathrm{~mm},{ }^{18}$ and $1 \mathrm{~mm}^{8}$ was used for the load. In two studies $^{12,13}$ a $6 \mathrm{~mm}$ diameter steatite ceramic balls were used to test fracture resistance. In one stu$\mathrm{dy},{ }^{14}$ a degusit ball (5 $\mathrm{mm}$ diameter) was used and in another study ${ }^{16}$ the load with a 6.25 diameter carbide ball was applied. Test methodologies and the machine set-up are summarized in Table 2.

Table 2. Test methodologies and the machine set-up

\begin{tabular}{|c|c|c|c|}
\hline Study & Testing machine & $\begin{array}{l}\text { Crosshead } \\
\text { speed }\end{array}$ & Test set-up \\
\hline $\begin{array}{l}\text { Xiaoqiong Huang } \\
\text { et al. [6], } 2020\end{array}$ & $\begin{array}{l}\text { Universal testing } \\
\text { machine (Instron } \\
\text { E3000, Instron } \\
\text { Ltd., Norwood, } \\
\text { Massachusetts, USA) }\end{array}$ & $0.5 \mathrm{~mm} / \mathrm{min}$ & $\begin{array}{l}\text { The load was applied parallel to the long } \\
\text { axis of the tooth using a stainless-steel } \\
\text { indenter with a diameter of } 4 \mathrm{~mm}\end{array}$ \\
\hline $\begin{array}{l}\text { Samah Saker et al. } \\
\text { [7], } 2021\end{array}$ & $\begin{array}{l}\text { Universal testing } \\
\text { machine (AG-5 kng, } \\
\text { Shimadzu, Kyoto, } \\
\text { Japan) }\end{array}$ & $0.5 \mathrm{~mm} / \mathrm{min}$ & $\begin{array}{l}\text { The load was directed at } 1 \mathrm{~mm} \text { from the } \\
\text { incisal edge on the tooth restoration in- } \\
\text { terface with a customized plunger. }\end{array}$ \\
\hline $\begin{array}{l}\text { Abdul Rahman et } \\
\text { al. [8], } 2020\end{array}$ & $\begin{array}{l}\text { Universal testing } \\
\text { machine (M350-5CT, } \\
\text { Testomatric, UK) }\end{array}$ & $0.5 \mathrm{~mm} / \mathrm{min}$ & $\begin{array}{l}\text { A locally manufactured customized } \\
\text { plunger (chisel shaped steel rod with its } \\
\text { flat end having a diameter of } 1 \mathrm{~mm} \text { and } \\
\text { a length of } 3 \mathrm{~mm} \text { ) was placed at the occ- } \\
\text { lusal surface of the veneer }\end{array}$ \\
\hline $\begin{array}{l}\text { Eun-Hye Jo et al. } \\
{[10], 2020}\end{array}$ & $\begin{array}{l}\text { Thermal cyclic tester; } \\
\text { R\&B inc }\end{array}$ & $0.5 \mathrm{~mm} / \mathrm{min}$ & $\begin{array}{l}\text { The stainless-steel rod ( } 6 \mathrm{~mm} \text { diameter) } \\
\text { at a static load contacted the palatal sur- } \\
\text { face } 1 \mathrm{~mm} \text { below the incisal edge at an } \\
\text { angle of } 135 \text { degrees. }\end{array}$ \\
\hline $\begin{array}{l}\text { F.O. Abulzze et al. } \\
{[11], 2018}\end{array}$ & $\begin{array}{l}\text { Biocycle V2 equip- } \\
\text { ment (Biopdi, São } \\
\text { Carlos, SP) }\end{array}$ & NA & $\begin{array}{l}\text { Specimens received a load through a } \\
\text { stainless-steel sphere with a } 4.6-\mathrm{mm} \text { - } \\
\text {-diameter indenter centered with three- } \\
\text {-point contacts. }\end{array}$ \\
\hline $\begin{array}{l}\text { Majed Al-Akhali } \\
\text { et al. [12], } 2019\end{array}$ & $\begin{array}{l}\text { Dual-axis computeri- } \\
\text { zed masticatory simu- } \\
\text { lator (Willytec) }\end{array}$ & $1800 \mathrm{~mm} / \mathrm{min}$ & $\begin{array}{l}6 \mathrm{~mm} \text { diameter steatite ceramic balls } \\
\text { were used as antagonists with a vertical } \\
\text { movement to stroke the buccal cusps } \\
\text { with a lateral sliding toward the central } \\
\text { fissure }\end{array}$ \\
\hline $\begin{array}{l}\text { Uwe Blunck } \\
\text { et al. [13], } 2020\end{array}$ & $\begin{array}{l}\text { Chewing simulator } \\
\text { (SD Mechatronik, } \\
\text { Feldkirchen- } \\
\text { Westerham, Germany) }\end{array}$ & $1020 \mathrm{~mm} / \mathrm{min}$ & $\begin{array}{l}\text { A special metal cone was used addi- } \\
\text { tionally to guarantee exact positioning } \\
\text { of the specimen during mechanical lo- } \\
\text { ading. }\end{array}$ \\
\hline $\begin{array}{l}\text { Katrin Heck et al. } \\
{[14], 2019}\end{array}$ & $\begin{array}{l}\text { Computer-controlled } \\
\text { chewing simulator } \\
\text { (MUC 2; Willytec } \\
\text { gmbh, Gräfelfing, } \\
\text { Germany) }\end{array}$ & $0.5 \mathrm{~mm} / \mathrm{min}$ & $\begin{array}{l}\text { A } 5 \mathrm{~mm} \text { Degussit-balls were used to } \\
\text { perform a natural mastication }\end{array}$ \\
\hline
\end{tabular}


Table 2. cont.

\begin{tabular}{|l|l|l|l||}
\hline $\begin{array}{l}\text { A. Ioannidis et al. } \\
\text { [15], 2020 }\end{array}$ & $\begin{array}{l}\text { Chewing simulator } \\
\text { (Williytec, Munich, } \\
\text { Germany) }\end{array}$ & $1 \mathrm{~mm} / \mathrm{min}$ & $\begin{array}{l}\text { A vertical indenter (rounded tip of } \square 8 \\
\text { mm) executed a vertical movement to } \\
\text { the occlusal plane. }\end{array}$ \\
\hline $\begin{array}{l}\text { Jose Carlos } \\
\text { Romanini Junior et } \\
\text { al. [16], 2020 }\end{array}$ & $\begin{array}{l}\text { Universal testing } \\
\text { machine (K2000 MP; } \\
\text { KRATOS, Sao Paulo, } \\
\text { Brazil) }\end{array}$ & $0.5 \mathrm{~mm} / \mathrm{min}$ & $\begin{array}{l}\text { A uniaxial compression load was applied } \\
30^{\circ} \text { off-axis bucally at the incisal edge } \\
\text { of the sample using a } 6.25 \mathrm{~mm} \text { tungsten } \\
\text { carbide ball (WC) }\end{array}$ \\
\hline $\begin{array}{l}\text { Mirelle Maria } \\
\text { Ruggiero et al. } \\
\text { [17], 2021 }\end{array}$ & $\begin{array}{l}\text { Universal testing ma- } \\
\text { chine (Instron 4411, } \\
\text { Corona, CA, USA) }\end{array}$ & $1 \mathrm{~mm} / \mathrm{min}$ & $\begin{array}{l}\text { A load applied axially through a tung- } \\
\text { sten carbide indenter on the central fossa } \\
\text { of the occlusal surface }\end{array}$ \\
\hline $\begin{array}{l}\text { Haoyu Zhang et al. } \\
\text { [18], 2020 }\end{array}$ & $\begin{array}{l}\text { Universal testing ma- } \\
\text { chine (Instron 5969, } \\
\text { Instron, Boston, IL) }\end{array}$ & $1.0 \mathrm{~mm} / \mathrm{min}$ & $\begin{array}{l}\text { A stainless steel sphere with a } 5.5-\mathrm{mm} \\
\text { diameter was used in parallel with the } \\
\text { long axis of the tooth in the occlusal } \\
\text { contact area. }\end{array}$ \\
\hline $\begin{array}{l}\text { Majed Al-Akhali } \\
\text { et al. [19], 2017 }\end{array}$ & $\begin{array}{l}\text { A dual-axis com- } \\
\text { puterized chewing } \\
\text { simulator (Willytec, } \\
\text { Feldkirchen- } \\
\text { Westerham, Germany) }\end{array}$ & $1800 \mathrm{~mm} / \mathrm{min}$ & $\begin{array}{l}\text { 6mm diameter steatite ceramic balls } \\
\text { were applied on the buccal cusp begin- } \\
\text { ning } 0.5 \text { mm below the cusp tip with } \\
\text { a lateral sliding component of } 0.3 \mathrm{~mm} \\
\text { towards the central fissure. }\end{array}$ \\
\hline
\end{tabular}

NA - not available

\section{Evaluation of material selection}

In all studies the impact of material type on fracture resistance was significant. Lithium disilicate ceramic (IPS E.max CAD) was examined in six studies $(46.2 \%)$, in five of them it was in a form of an occlusal veneer ${ }^{8,12,14,18,19}$ and in one study it was applied to incisors. ${ }^{16}$ Lithium disilicate (IPS E. max Press) was used in three studies. ${ }^{6,15,18}$ Polymer infiltrated ceramic was used in five studies $8,11,12,17,19(38.5 \%)$ for occlusal veneers. It is known as, "hybrid cev ramic" (Vita Enamic) and combines the advantages of both composites and all-ceramic restorations. Zirconia reinforced lithium silicate (Vita Suprinity) was used in three studies. ${ }^{11,12,19}$ Composite, which is also indicated for veneers, was chosen in five studies: nanoceramic resin (Lava Ultimate CAD/CAM) was employed in three studies, in two of them as occlusal veneers, ${ }^{14,17}$ and in one study for anterior veneers manufacture, ${ }^{16}$ microhybrid resin (Ceramage
Shofu) was used for occlusal veneers in one study, ${ }^{18}$ and fibre-reinforced microhybrid resin (ever Stick C\&B) was also used for occlusal veneers in one ${ }^{18}$ study. Zirconia-reinforced lithium silicate (Vita Suprinity) was applied in three studies ${ }^{11,12,19}$ and 3D printed (Lithoz) $)^{15}$, milled $\left(\right.$ Ceramil Zolid Fx) ${ }^{15}$, and monolithic (Zolid Fx preshade $)^{7}$ zirconia was also chosen in three studies. Polymethylmethacrylate (Telio CAD) for occlusal veneers was used in two studies ${ }^{12}$, ${ }^{19}$, therefore two studies ${ }^{13,14}$ used leucite reinforced glass ceramic (IPS Inline, IPS Empress CAD). Felspathic ceramic (Cercon ceram kiss, Vita Blocks Mark II) was employed in two studies, ${ }^{10,16}$ One study ${ }^{10}$ used metal ceramic (Shofu Vintage Halo). The materials used in each study are presented in Table 3.

\section{Discussion}

The aim of this literature review was to investigate the most commonly used laminate 
Ta b le 3. Representation of restoration materials used in each study

\section{Study}

Xiaoqiong Huang et al. [6], 2020

Samah Saker et al. [7], 2021

Abdul Rahman et al. [8], 2020

Eun-Hye Jo et al. [10], 2020

F.O. AbuIzze et al. [11], 2018

Majed Al-Akhali et al. [12], 2019

Uwe Blunck et al. [13], 2020

Katrin Heck et al. [14], 2019

A. Ioannidis et al. [15], 2020

Jose Carlos Romanini Jr et al. [16], 2020

Mirelle Maria Ruggiero et al. [17], 2021

Haoyu Zhang et al. [18], 2020

Majed Al-Akhali et al. [19], 2017

$$
\begin{array}{l|l|l|l|l|l|l|l|l|}
\multicolumn{8}{c}{\text { Material }} \\
\hline \text { Z-RLS } & \text { HC } & \text { LD } & \text { LR-GC } & \text { C } & \text { Z } & \text { FC } & \text { MC } & \text { P }
\end{array}
$$

Z-RLS - zirconia reinforced lithium silicate; HC - hybric ceramic; LD - lithium disilicate; LR-GC leucite reinforced glass ceramic; $\mathrm{C}$ - composite; $\mathrm{Z}$ - zirconia; $\mathrm{FC}$ - feldspathic ceramic; $\mathrm{MC}$ - metal ceramic; $\mathrm{P}$ - polymethylmethacrylate.

veneer materials (lithium disilicate, feldspatic ceramic, zirconia-reinforced lithium silicate) with regard to their fracture resistance. As mentioned before, 481 publications were found, of which 13 were identified as relevant to the topic and were therefore analysed. It is important to note that in eight studies $7,8,10,12,13,15,18,19$ thermomechanical aging was performed. In three studies ${ }^{6,11,14}$ specimens were subjected to fracture resistance tests after cyclic loading. The step-stress accelerated life-testing (SSALT) test was applied in two studies. ${ }^{16,17}$ It is important to mention that various aging methods are suggested to evaluate the durability of restorative materials used in a laboratory setting. When testing fractures, with the exception of aging protocols such as water storage, thermocycling or thermo-mechanical aging, two methods could also be applied - sciliced load to failure test or accelerated fatigue test. Alas, no consensus is currently available as to which method of durability tests would simulate the intra-oral environment the most accurately. ${ }^{20}$ After analysing chosen studies it is possible to conclude that zirconia-lithium disilicate exhibited the most prominent favourable results in fracture resistance. Furthermore, resin nanoceramic veneers and fiber-reinforced micro hybrid composite exhibited quite high resistance to fracture when compared to other materials. Evidently, the long-term prognosis of the ceramic laminates is highly dependent on the 
material from which they were manufactured. In addition to that, various other factors such as tooth preparation depth, ceramic thickness, and cementation material can affect durability of LV. Failures in ceramic laminate veneers (CLVs) have been related to microcracks and the fracture of the ceramic or the tooth structure itself.

It is of interest to collate the ability to dissipate calamitous fracture forces by the application of materials' ability to contort. It has been scientifically proven that ceramics discern ina flated elastic modulus at65-90 GPa. For composite resins it is $1.6-12.4 \mathrm{GPa}$. Less resilient materials, also referred as brittle materials, do not undergo significant elastic de-formations (Niem et al., 2019) ${ }^{21}$ which means that when subjected to stresses they absorb little energy and break shortly after. Composite resins are specifically characterized by possessing excessive values of fracture strength, as they are more resilient and have the ability to successfully disperse the applied stress. ${ }^{22}$ However, there are contradicting studies that show significantly better performance of ceramic veneers in comparison with indirect composite ones. ${ }^{23}$ Nowadays it is becoming apparent that quickly developing modern technology highly impacts dentistry and enables substantially less invasive teeth preparation for indirect restorations, thus more dental tissues are left intact and the used restoration can be less extensive. As a result, it can be seen that ceromers and ceramic materials such as zirconium are used more frequently due to their ability to provide an ameliorated aesthetic appearance. They also withstand high functional forces generated by the teeth during the mastication process. Yet, when collating with composite restorations, the main difference is evident: composite restorations can be applied in a single session, whereas ceromers and ceramic restorations require more time and precision during the positioning and cementation stages in clinics. Furthermore, referred materials compel technical caution during the production in the laboratory. Composite resin, on the other hand, has supplementary disadvantages, such as low fragility resistance, surface roughness, and polymerization shrinkage that generate less satisfactory clinical results. Subsequently, the choice of the restoration material has to be based on both the patient's aesthetic priorities and the functional properties of the material itself. ${ }^{24}$ Thus, future studies should be performed for an even better evaluation of the discussed materials.

Moreover, there are studies that underline the influence of preparation depth on fracture resistance. Clinical studies show that restorations placed on dentine are more prone to fracture than those placed solely on enamel. They suggest that retaining the maximal amount of enamel surface area after tooth preparation is paramount and that it will assist better at resisting catastrophic failure. In these studies, it is evident, that veneer preparations on half-enamel-half-dentine behave essentially like those placed on all-dentine substrates with respect to catastrophic failure loads. The given data dispel the notion that having $50 \%$ of the enamel remaining after the preparation is in any way comparable to an all-enamel preparation; instead, it was directly comparable to an alldentine preparation. Consequently, ${ }^{25}$ it is important to note that the technique without any tooth preparation requires careful finishing and polishing because of the difficulty in obtaining a smooth transition and avoiding overhangs. ${ }^{25}$ Furthermore, the thin margins are exposed to a risk of failure by chipping and cracking caused by shrinkage during light polymerization of the luting materials. ${ }^{26}$ In other studies, it is reported that for the maximum decrease of stress in the porcelain restoration and the ability to obtain optimal bond, the preparation depth should include enamel only. Therefore, the technique of surface preparation plays a vital role to maintain the longevity of the porcelain laminate 
veneers, since extensively exposed dentine surn faces cause high failure rates. Thus, more studies of preparation depth impact on fracture resistance should be conducted for proper evaluation.

As mentioned before, the thickness of allceramic restorations also plays an important role in the fracture resistance and their clinical performance is highly related to the previously mentioned tooth preparation depth. Studies have shown that occlusal lithium disilicate ceramic veneers with a thickness of $0.6-1.0 \mathrm{~mm}$ and 1.2-1.8 mm can resist forces of up to $800 \mathrm{~N}$ and $1000 \mathrm{~N}$, respectively. In a study by Sasse et al., the fracture resistance of occlusal veneers made of lithium disilicate ceramics was examined. ${ }^{27}$ The specimens were produced in different thicknesses and bonded to different substrates. It turned out that the thickness of the occlusal veneers should not be less than 0.7$1.0 \mathrm{~mm}$ regardless of the substrate. ${ }^{27}$ In general, it was found that a minimally invasive preparation without dentine exposure combined with thicker veneers $(>0.5-1.2 \mathrm{~mm})$ showed an increased adhesion. Consequently, an invasive preparation with $100 \%$ buccal dentine exposure, which was restored with thin ceramic veneers, showed the most pronounced adhesive defects. ${ }^{28}$

It is important to mention that for the longterm clinical success durable adhesive luting is required since laminate veneers do not rely on mechanical retention principles. This is why it is important to note that luting also highly impacts veneer resistance to fracture and that is why proper luting agent must be chosen. Auto-, light-, or dual-polymerizing resin cements are currently obtainable and recommended for luty ing ceramic restorations. ${ }^{29}$ However, despite various possibilities for the luting of LVs, in most laboratory and clinical studies a photopolymerized resin composite is advised. The above-mentioned resin luting agent has sevt eral advantages over dual-polymerized ones.
Photo-polymerized resin cements possess fae vourable handling properties that increase the time that is required for restoration seating. Furthermore, in some studies, photo-polymerized resin materials showed significantly better bond strength when compared to dual-polymerized resin cements. ${ }^{20}$

It is of interest to mark that there are findings in some studies that suggest the significance of preparation surface being superior to the resin cement type on shear bond strength. Besides, there was no notable contrast when three resin cements were compared in the descriptive stai tistics. In conclusion, it can be stated that both light-cured and dual-curied resin showed equally beneficial properties within the limitations of this study. Nevertheless, a higher number of studies must be performed to better analyse the impact of bond strength on fracture resistance.

\section{Conclusions}

Based on the findings of this literature review on laminate veneers manufactured from various materials, the following conclusions have been drawn. First and foremost, zirconia-reinforced lithium silicate and resin nanoceramic veneers show superior resistance to fracture in comparison with zirconia-feldspathic porcelain, metal ceramic, polymer-infiltrated ceramic, fibre-reinforced micro hybrid composite, Vita Enamic hybrid ceramic, polymethylmethacrylate group, heat-pressed lithium disilicate, and lithium disilicate-reinforced ceramic. Secondly, the risk of veneering restoration material fractures increases significantly, when anterior veneer preparations are less or equal $0.5 \mathrm{~mm}$ Thirdly, ceramic veneer restoration materials are more prone to fractures, when the preparations include medium to high dentine portions, approximately $\geq 50 \%$, in comparison with thicker veneers with preparations in enamel or partially in dentine $<50 \%$. In addition to that, it can be concluded that the involvement of substantial 
tooth structure causes higher probability of fracture occurrence. As the final point, standard sintering procedure was proven to cause a lower percentage of cohesive failure occurrences on the translucent zirconia laminate veneers when compared to speed sintering.

\section{References}

1. Lee $S-M$, Choi $Y$-S: Effect of ceramic material and resin cement systems on the color stability of laminate veneers after accelerated aging. J Prosthet Dent 2018; 120: 99-106.

2. Jurado C, AlResayes S, Sayed M, VillalobosTinoco J, Llanes-Urias N, Tsujimoto A: A customized metal guide for controllable modification of anterior teeth contour prior to minimally invasive preparation. Saudi Dent J 2020.

3. Alothman Y, Bamasoud M: The Success of Dental Veneers According To Preparation Design and Material Type. Open Access Maced J Med Sci 2018; 6: 2402-2408.

4. Sulaiman T, Abdulmajeed A, Delgado A, Donovan T: Fracture rate of 188695 lithium disilicate and zirconia ceramic restorations after up to 7.5 years of clinical service: A dental laboratory survey. J Prosthet Dent 2020; 123: 807-810.

5. Souza R, Barbosa F, Araújo G, et al.: Ultrathin Monolithic Zirconia Veneers: Reality or Future? Report of a Clinical Case and Oneyear Follow-up. Oper Dent 2018; 43: 3-11.

6. Huang X, Zou L, Yao R, Wu S, Li Y: Effect of preparation design on the fracture behavior of ceramic occlusal veneers in maxillary premolars. J Dent 2020; 97: 103346.

7. Saker S, Özcan M: Marginal discrepancy and load to fracture of monolithic zirconia laminate veneers: The effect of preparation design and sintering protocol. Dent Mater J 2021; 40: 331-338.

8. Saleh A, Al-Ani M, ALRawi T, Al-Edressi G: An in-vitro comparison of fracture resistance of three CAD/CAM Ceramic materials for fabricating Veneer. Saudi Dent J 2020.

9. Rathi S, Verma A: Material selection for single-tooth crown restorations. Applications of Nanocomposite Materials in Dentistry 2019; p. 225-235.

10. Jo E, Huh Y, Ko K, Park C, Cho L: Effect of different ceramic materials and substructure designs on fracture resistance in anterior restorations. J Prosthet Dent 2020.

11. Abu-Izze FO, Ramos GF, Borges ALS, Anami $L C$, Bottino MA: Fatigue behavior of ultrafine tabletop ceramic restorations. Dent Mater 2018; 34: 1401-1409.

12. Al-Akhali M, Kern M, Elsayed A, Samran A, Chaar MS: Influence of thermomechanical fatigue on the fracture strength of cad-camfabricated occlusal veneers. J Prosthet Dent 2019; 121: 644-650.

13. Blunck $U$, Fischer $S$, Hajtó J, Frei $S$, Frankenberger $R$ : Ceramic laminate veneers: Effect of preparation design and ceramic thickness on fracture resistance and marginal quality in vitro. Clinical Oral Investigations 2020; 24: 2745-2754.

14. Heck K, Paterno H, Lederer A, Litzenburger $F$, Hickel $R$, Kunzelmann $K-H$ : Fatigue resistance of ultrathin $\mathrm{Cad} / \mathrm{cam}$ ceramic and Nanoceramic Composite occlusal veneers. Dent Mater 2019; 35: 1370-1377.

15. Ioannidis A, Bomze D, Hämmerle CHF, Hüsler J, Birrer $O$, Mühlemann S: Loadbearing capacity of CAD/CAM 3D-PRINTED ZIRCONIA, CAD/CAM milled zirconia, and heat-pressed lithium disilicate Ultra-thin occlusal veneers on molars. Dent Mater 2020; 36. 
16. Romanini-Junior JC, Hirata $R$, Bonfante $E A$, et al.: Monolithic CAD/CAM laminate veneers: Reliability and failure modes. Dent Mater 2020; 36: 724-732.

17. Ruggiero MM, Soares Gomes R, Pedroso Bergamo ET, Freitas MI, Bonfante EA, Del Bel Cury AA: Resin-matrix ceramics for occlusal veneers: Effect of thickness on reliability and stress distribution. Dent Mater 2021; 37.

18. Zhang H, Lv P, Du W, Jiang T: Comparison of fracture load and Surface wear Of Microhybrid composite and Ceramic Occlusal Veneers. J Prosthodont 2020; 29: 387-393.

19. Al-Akhali M, Chaar MS, Elsayed A, Samran A, Kern M: Fracture resistance of ceramic and polymer-based occlusal veneer restorations. Journal of the Mechanical Behavior of Biomedical Materials 2017; 74: 245-250.

20. Gresnigt MMM, Özcan M, Carvalho M, et al.: Effect of luting agent on the load to failure and accelerated-fatigue resistance of lithium disilicate laminate veneers. Dent Mater 2017; 33: 1392-1401.

21. Niem T, Youssef N, Wöstmann B: Energy dissipation capacities of cad-cam restorative materials: A comparative evaluation of resilience and toughness. T J Prosthet Dent 2019; 121: 101-109.

22. Gresnigt MMM, Sugii MM, Johanns $K B F W$, van der Made SAM: Comparison of conventional ceramic laminate veneers, partial laminate veneers and direct composite resin restorations in fracture strength after aging. Journal of the Mechanical Behavior of Biomedical Materials 2021; 114: 104172.

23. Gresnigt MMM, Cune MS, Jansen K, van der Made SAM, Özcan M: Randomized clinical trial on indirect resin composite and ceramic laminate veneers: Up to 10-year findings. J Dent 2019; 86: 102-109.
24. Yıldırım Z, Gömeç ÖY: Treatment approaches for traumatized anterior teeth with excessive TISSUE loss: Three case reports. J Istanbul University Faculty Dent 2017; 51.

25. Ge C, Green CC, Sederstrom DA, McLaren $E A$, Chalfant JA, White $S N$ : Effect of tooth substrate and porcelain thickness on porcelain veneer failure loads in vitro. T J Prosthet Dent 2018; 120: 85-91.

26. Bragança GF, Mazão JD, Versluis A, Soares $C J$ : Effect of luting materials, presence of tooth preparation, and functional loading on stress distribution on ceramic laminate veneers: A finite element analysis. T J Prosthet Dent 2021; 125: 778-787.

27. Krummel A, Garling A, Sasse M, Kern M: Influence of bonding surface and bonding methods on the fracture resistance and survival rate of full-coverage occlusal veneers made from lithium disilicate ceramic after cyclic loading. Dent Mater 2019; 35: 13511359.

28. Haak R, Siegner J, Ziebolz D, et al.: OCT evaluation of the internal adaptation of ceramic veneers depending on preparation design and Ceramic thickness. Dent Mater 2021; 37: 423-431.

29. Marchionatti AM, Wandscher VF, May MM, Bottino MA, May LG: Color stability of ceramic laminate veneers cemented with light-polymerizing and dual-polymerizing luting agent: A split-mouth randomized clinical trial. J Prosthet Dent 2017.

Zaakceptowano do druku: 7.12.2021 r.

Adres autorów: Faculty of Odontology,

Medical Academy, Lithuanian

University of Health sciences,

Kaunas, Lithuania

(C) Zarząd Główny PTS 2021. 